\title{
Bcl-2 induces pro-oxidant state by engaging mitochondrial respiration in tumor cells
}

\author{
ZX Chen ${ }^{1,2}$ and S Pervaiz ${ }^{\star, 1,2,3}$
}

Mitochondrial respiration, the key process behind cellular energy production, is critical for cell proliferation, growth and survival. However, the regulation of mitochondrial respiratory function in tumor cells is not well understood. In this study, we propose a model whereby tumor cells possess the capacity to fine-tune the balance between energy demands and mitochondrial reactive oxygen species (ROS) status, to maintain a milieu optimal for survival. This is achieved through the moderation of mitochondrial respiration, depending on the ROS context within the organelle, with the main players being Bcl-2 and cytochrome $c$ oxidase (COX). We report a higher level of COX activity, oxygen consumption and mitochondrial respiration in tumor cells overexpressing Bcl-2. Transient overexpression, gene silencing and pharmacological inhibition of Bcl-2 corroborate these findings. Interestingly, Bcl-2 is also able to regulate mitochondrial respiration and COX activity in the face of mounting ROS levels, triggered by mitochondrial complex inhibitors. In this respect, it is plausible to suggest that Bcl-2 may be able to create an environment, most suited for survival by adjusting mitochondrial respiration accordingly to meet energy requirements, without incurring an overwhelming, detrimental increase in intracellular ROS.

Cell Death and Differentiation (2007) 14, 1617-1627; doi:10.1038/sj.cdd.4402165; published online 18 May 2007

Cancer is a multifactorial disease orchestrated by dysregulated cellular pathways that control cell fate decisions. Despite recent strides in our understanding of the biology of the transformed phenotype, several critical effector pathways remain unexplained. Among these, the involvement of mitochondrial respiration and function in the process of carcinogenesis is far from clear. Recent interest has focused on the role of metabolism such as mitochondrial respiration and the glycolytic pathway, whereby p53 was shown to be involved in both by mediating the expression of TP53-induced glycolysis and apoptosis regulator and synthesis of cytochrome $c$ oxidase (COX) $2 .^{1-3}$

However, little correlation has been shown to address whether the effect of antiapoptotic proteins such as Bcl-2 extends to mitochondrial function, pertaining to the electron transport chain (ETC) and mitochondrial respiration. Bcl-2 is largely localized to the mitochondria, with many of its protective effects centering on mitochondrial membrane integrity and sequestration of proapoptotic proteins. ${ }^{4-6}$ However, mitochondrial respiration, a major source of reactive oxygen species (ROS), remains loosely connected to this 'resident' protein of the mitochondria. ${ }^{7,8}$

Recent work paved the way for a possible link between $\mathrm{Bcl}-$ 2 and mitochondrial respiration by suggesting that leukemia cells overexpressing $\mathrm{Bcl}-2$ promote a slight pro-oxidant state, permissive for cell survival. ${ }^{9}$ The role of $\mathrm{Bcl}-2$ as a pro-oxidant protein in live animal models has also been reflected in other model systems. ${ }^{10}$ If this scenario were indeed true, it would be of great interest to identify the cellular source(s) of superoxide
$\left(\mathrm{O}_{2}^{-}\right)$. Because the mitochondria has been widely regarded as the main consumer of molecular oxygen as well as ROS production, it appears logical to investigate the role of mitochondria in this pro-oxidant state. ${ }^{7,8}$ Given the localization of $\mathrm{Bcl}-2$ to the mitochondria it became compelling to investigate if the protein plays a role in generating a slight pro-oxidant state by engaging the mitochondria machinery. $7,8,11,12$

One of the key mitochondrial proteins is COX, the fourth complex and the rate-limiting step of the ETC, where it expends the majority of oxygen for reduction by cytochrome $c$ to produce water, and as a result generates adenosine triphosphate (ATP) via oxidative phosphorylation. ${ }^{2,13}$ Given the antiapoptotic nature of $\mathrm{Bcl}-2$ and the functional significance of COX in mitochondrial respiration, here we investigated the role of $\mathrm{Bcl}-2$ in mitochondrial respiration with relation to COX and the subsequent downstream effects. We present evidence that cancer cells overexpressing Bcl-2 have greater basal COX activity and oxygen consumption as compared to mock-transfected cells. More intriguingly, an abundance of $\mathrm{Bcl}-2$ empowers the cell to sense mitochondrial oxidative stress and respond by regulating mitochondrial respiration accordingly at the level of COX, and in so doing maintains mitochondrial ROS status at a manageable level. With these findings, we propose a model whereby $\mathrm{Bcl}-2$ is able to promote mitochondrial respiration under normal conditions for a pro-oxidant state to drive proliferation signals. However, in the wake of stress triggers such as overwhelming ROS production, $\mathrm{Bcl}-2$ regulates mitochondrial respiration and

\footnotetext{
${ }^{1}$ Department of Physiology, Yong Loo Lin School of Medicine, National University of Singapore, Singapore; ${ }^{2}$ NUS Graduate School for Integrative Sciences and Engineering, National University of Singapore, Singapore and ${ }^{3}$ Singapore-MIT Alliance, Singapore

${ }^{*}$ Corresponding author: S Pervaiz, NUS Graduate School for Integrative Sciences and Engineering, Department of Physiology, YLL School of Medicine, National University of Singapore, Singapore 117597. Tel: + 65 65166602; Fax: + 65 67788161; E-mail: phssp@ nus.edu.sg

Keywords: Bcl-2; COXs1; mitochondrial respiration; superoxide; tumor cells

Abbreviations: ROS, reactive oxygen species; COX, cytochrome $c$ oxidase; ETC, electron transport chain

Received 23.10.06; revised 05.4.07; accepted 09.4.07; Edited by P Bouillet; published online 18.5.07
} 
draws the line between the need for energy and keeping ROS levels under homeostatic control, so as to increase the cancer cell's propensity to survive under harsh conditions.

\section{Results}

CEM/Bcl-2 cells exhibit higher levels of intracellular and intramitochondrial $\mathrm{O}_{2}^{-}$than $\mathrm{CEM} / \mathrm{Neo}$ cells. Although previous reports suggest an antioxidant function for $\mathrm{Bcl}-2$ by reinforcing cellular antioxidative defenses in response to its self-induced ROS production, our observations provide insight into the role of $\mathrm{Bcl}-2$ in creating a slight pro-oxidant intracellular milieu in tumor cells. ${ }^{14-16}$ Corroborating our earlier report, $\mathrm{CEM} / \mathrm{Bcl}-2$ cells had moderately higher levels of $\mathrm{O}_{2}^{-}$than $\mathrm{CEM} / \mathrm{Neo}$ cells (Figure 1a). In addition, isolated mitochondria from $\mathrm{CEM} / \mathrm{Bcl}-2$ cells were shown to have higher $\mathrm{O}_{2}^{-}$as compared to those of CEM/Neo cells, assessed by a lucigenin-based chemiluminescence assay and a flow cytometry-based assay using MitoSOX Red (Figure 1b and c).
Cancer cells overexpressing Bcl-2 have increased coupled mitochondrial respiration and COX activity. Measurement of COX activity revealed that both HeLa/Bcl-2 and $\mathrm{CEM} / \mathrm{Bcl}-2$ cells had higher activity than their non-overexpressing counterparts. In addition, $N, N, N, N$ tetramethylbenzene-1,4-diamine (TMPD)/ascorbate-driven mitochondrial respiration displayed higher oxygen consumption in $\mathrm{CEM} / \mathrm{Bcl}-2$ cells than $\mathrm{CEM} / \mathrm{Neo}$ cells, translatable to a higher level of COX activity in CEM/Bcl-2 cells (Figure 2a). This is in concordance with the data from COX activity assays. Increased COX activity will expectedly enhance mitochondrial respiration, with increased ROS production being a derivative. Similarly, succinate-driven mitochondrial oxygen consumption was also higher in $\mathrm{CEM} / \mathrm{Bcl}-2$ cells than $\mathrm{CEM} / \mathrm{Neo}$ cells (Figure 2b). With COX activity assay and oxygen consumption measurement, we showed that both the oxidative and reductive capacities of COX were enhanced in the context of increased Bcl-2 expression. Furthermore, CEM/ $\mathrm{Bcl}-2$ cells also displayed higher mitochondrial respiration than CEM/Neo cells upon incubation with the uncoupler carbonyl cyanide $m$-chlorophenyl-hydrazone (CCCP), implying an
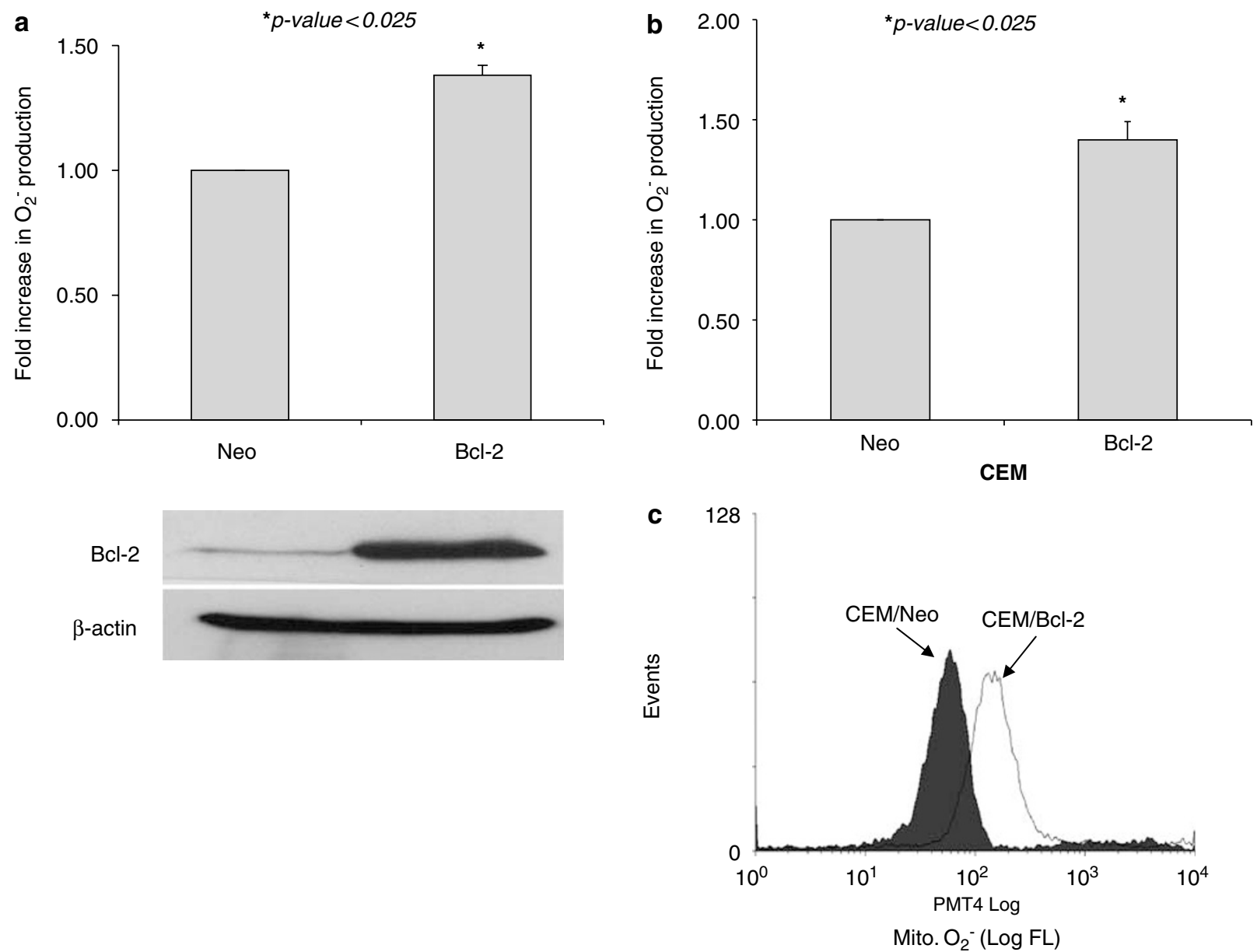

Figure $1 \mathrm{CEM}$ cells overexpressing Bcl-2 have elevated levels of intracellular and intramitochondrial $\mathrm{O}_{2}^{-}$. (a) Intracellular $\mathrm{O}_{2}^{-}$is elevated in $\mathrm{CEM} / \mathrm{Bcl}-2$ cells. Using lucigenin-based chemiluminescence assay, $\mathrm{O}_{2}^{-}$production was determined between $\mathrm{CEM} / \mathrm{Neo}$ and $\mathrm{CEM} / \mathrm{BCl}-2 \mathrm{cell}$ s. Overexpression of $\mathrm{Bcl}-2$ is evident in $\mathrm{CEM} / \mathrm{Bcl}-2 \mathrm{cellls}$ as confirmed by Western blot analysis. (b) The observation was confirmed by lucigenin assay when performed on isolated mitochondria from the different cell lines. (c) Using MitoSOX Red probe, mitochondrial $\mathrm{O}_{2}^{-}$was shown to be greater in CEM/Bcl-2 cells as compared to CEM/Neo cells. The error bars in $\mathbf{a}$ and $\mathbf{b}$ represent the mean \pm s.d $(n=3)$ 


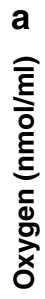
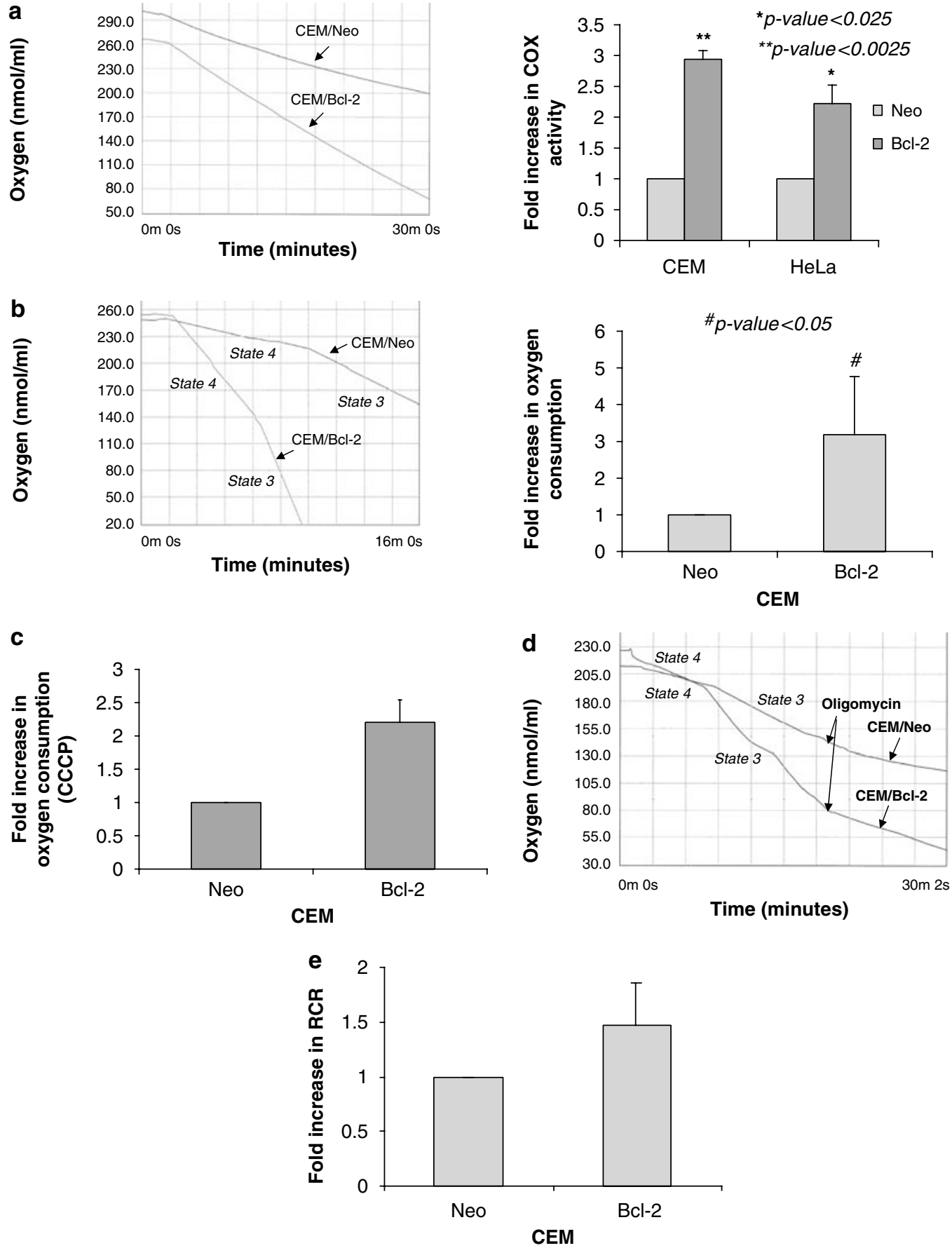

Figure 2 Mitochondrial respiration is augmented in Bcl-2 overexpressing tumor cells. (a) Oxygen consumption profile of isolated mitochondria from CEM cells respiring on TMPD/ascorbate. COX activity is enhanced in tumor cells overexpressing Bcl-2. Both HeLa and CEM cells were subjected to COX activity assay, spectrophotometrically determining the rate of $\mathrm{COX}$ activity through the addition of reduced cytochrome $c$. (b) $\mathrm{CEM} / \mathrm{Bcl}-2$ cells consumed more oxygen than $\mathrm{CEM} / \mathrm{Neo}$ cells. Oxygen consumption was assessed in isolated mitochondria, respiring on succinate in the presence of ATP to simulate state 4 respiration. Reverse electron flow was inhibited by rotenone. State 3 respiration was initiated by ADP. (c) CEM/Bcl-2 mitochondria showed a greater rate of CCCP-induced uncoupled respiration than CEM/Neo. (d) Inhibition of ATP synthase by oligomycin inhibits state 3 respiration. Isolated mitochondria from CEM/Bcl-2 cells exhibited greater respiration than CEM/Neo cells, independent of ATP phosphorylation and synthesis. (e) Respiratory control ratio (RCR) showed more tightly coupled respiration in isolated CEM/Bcl-2 mitochondria than CEM/Neo. The error bars in a-c and e represent the mean $\pm \mathrm{s} . \mathrm{d}(n=3)$

intrinsic increase in electron flux across the ETC of CEM/Bcl-2 mitochondria (Figure 2c). Oligomycin inhibited ATP synthase and abolished state 3 respiration in both CEM cell lines; however, oxygen consumption remained higher in $\mathrm{CEM} / \mathrm{Bcl}-2$ cells than CEM/Neo cells (Figure 2d). Succinate-initiated mitochondrial respiration in $\mathrm{CEM} / \mathrm{Bcl}-2$ cells displayed seemingly better coupling capabilities than CEM/Neo cells (Figure 2e). 
Bcl-2 expression exerts an effect on COX activity and impacts subsequent $\mathrm{O}_{2}^{-}$production. HeLa/Neo cells were transiently transfected with $\mathrm{bcl}-2$ to provide us with another tumor model to test our hypothesis. Overexpression of Bcl-2 observed $24 \mathrm{~h}$ after transfection correlated with the increase in COX activity in these cells (Figure $3 a$ and b). Correspondingly, intracellular $\mathrm{O}_{2}^{-}$level in these post- $24 \mathrm{~h}$ transfectants also increased (Figure $3 \mathrm{c}$ ). In contrast, using $\mathrm{Bcl}-2$-specific siRNA, the expression of Bcl-2 was markedly reduced in $\mathrm{HeLa} / \mathrm{Bcl}-2$ cells $48 \mathrm{~h}$ after transfection (Figure 3d). Silencing of Bcl-2 effected a decrease in COX activity, which correlated with a drop in intracellular $\mathrm{O}_{2}^{-}$level in these Bcl-2-silenced cells (Figure $3 e$ and f). Silencing of $\mathrm{Bcl}-2$ resulted in the reversal of observations obtained from our transient overexpression studies, further corroborating the likelihood of a functional association between COX and $\mathrm{Bcl}-2$. Moreover, treatment of $\mathrm{CEM} / \mathrm{Bcl}-2$ cells with $4 \mu \mathrm{M}$ HA14-1 (BH3 inhibitor) for $2 \mathrm{~h}$ resulted in decreased oxygen consumption of isolated mitochondria (Figure $3 \mathrm{~g}$ ). In contrast, CEM/Neo cells treated likewise with HA14-1 elicited an increase in oxygen consumption (Figure $3 \mathrm{~g}$ ). This observation was analogous to an earlier report on the effect of HA14-1 on mitochondrial respiration in CEM cells. ${ }^{17}$ Reduction in oxygen consumption of HA14-1-treated CEM/ $\mathrm{Bcl}-2$ cells was neither a result of decreased cell viability nor a reduction in Bcl-2 expression (Supplementary Figure S1 A, $B)$. Functional inhibition of Bcl-2 resulted in reduced oxygen consumption in the mitochondria of $\mathrm{CEM} / \mathrm{Bcl}-2$ cells, reiterating the involvement of $\mathrm{Bcl}-2$ in mitochondrial respiration.

If $\mathrm{Bcl}-2$ overexpression is indeed responsible for higher COX activity and oxygen consumption, which in turn induces a pro-oxidant state, then inhibition of COX should theoretically bring down $\mathrm{O}_{2}^{-}$production. The dose-dependent inhibition profile of COX activity by sodium azide revealed that $100 \mu \mathrm{M}$ sodium azide was sufficient to reduce COX activity and oxygen consumption in CEM/Bcl-2 cells to a level similar to that of untreated CEM/Neo cells (Figure $3 \mathrm{~h}$ ). Using the same concentration of sodium azide, intramitochondrial $\mathrm{O}_{2}^{-}$in $\mathrm{CEM} /$ $\mathrm{Bcl}-2$ cells was reduced to a level similar to that of untreated CEM/Neo cells (Figure $3 \mathrm{i}$ ).

Homeostatic regulation of mitochondrial respiration and COX activity in tumor cells overexpressing $\mathrm{Bcl}-2$ during oxidative stress. Antimycin A has been shown to induce intramitochondrial ROS production by inhibiting Complex III. ${ }^{2}$ We treated isolated mitochondria with $5 \mu \mathrm{g} / \mathrm{ml}$ antimycin A, which was sufficient to inhibit succinate-driven oxygen consumption and increase $\mathrm{O}_{2}^{-}$production from the isolated mitochondria of both $\mathrm{CEM} / \mathrm{NeO}$ and $\mathrm{CEM} / \mathrm{Bcl}-2$ cells almost immediately (Supplementary Figure S2). Using this property of antimycin $\mathrm{A}$, both $\mathrm{CEM} / \mathrm{Neo}$ and $\mathrm{CEM} / \mathrm{Bcl}-2$ cells were treated for $1 \mathrm{~h}$ with the concentration of antimycin $\mathrm{A}(5 \mu \mathrm{g} / \mathrm{ml})$ required to induce oxidative stress. Oxygen consumption was initiated and measured in isolated mitochondria, respiring on $1 \mathrm{mM}$ TMPD and $5 \mathrm{mM}$ ascorbate. Comparing TMPD/ascorbate-driven mitochondrial respiration, oxygen consumption in antimycin A-treated $\mathrm{CEM} / \mathrm{Bcl}-2$ cells was similar to that of treated $\mathrm{CEM} / \mathrm{Neo}$ cells (Figure 4a). Intriguingly, antimycin A-treated $\mathrm{CEM} / \mathrm{Bcl}-2$ cells failed to exhibit the kind of increase in oxygen consumption over their $\mathrm{CEM} / \mathrm{Neo}$ counterparts observed in our earlier experiments. More importantly, the increase in mitochondrial respiration of untreated $\mathrm{CEM} / \mathrm{Bcl}-2$ cells (over $\mathrm{CEM} / \mathrm{Neo}$ cells) was abolished upon direct antimycin $A$ treatment of isolated mitochondria (Figure 4b). Furthering this, TMPD/ascorbateinduced respiration was assessed in both CEM cell lines with or without antimycin A treatment using equal amounts of mitochondria. Isolated mitochondria from treated CEM/Neo cells exhibited an increase in oxygen consumption, whereas mitochondria from treated $\mathrm{CEM} / \mathrm{Bcl}-2$ cells demonstrated a reduction in oxygen consumption (Figure 4c). Moreover, oxidative stress induced by serum deprivation for $24 \mathrm{~h}$ resulted in greater succinate-driven oxygen consumption in $\mathrm{CEM} / \mathrm{Neo}$ than $\mathrm{CEM} / \mathrm{Bcl}-2$ isolated mitochondria, even though serum deprivation resulted in uncoupled respiration in both cell lines (Figure $4 d$ ). ${ }^{18}$

$\mathrm{CEM} / \mathrm{Neo}$ and $\mathrm{CEM} / \mathrm{Bcl}-2$ cells were subjected to $1 \mathrm{~h}$ of $5 \mu \mathrm{g} / \mathrm{ml}$ antimycin A or $5 \mu \mathrm{M}$ rotenone treatment before the isolation of COX and its activity assay were performed. Rotenone has been shown to produce $\mathrm{O}_{2}^{-}$in the context of complex I inhibition. ${ }^{19,20}$ With respect to antimycin A treatment, COX activity in treated CEM/Bcl-2 cells decreased in contrast to the increase observed in treated CEM/Neo cells (Figure 4e). Increase in COX activity in rotenone-treated $\mathrm{CEM} / \mathrm{Bcl}-2$ cells appeared to be more restrained than similarly treated CEM/Neo cells (Figure 4e). Similarly, HeLa/Neo and $\mathrm{HeLa} / \mathrm{Bcl}-2$ cells treated for $1 \mathrm{~h}$ with increasing concentrations of antimycin $\mathrm{A}$ resulted in increased COX activity in $\mathrm{HeLa} / \mathrm{NeO}$ cells, whereas $\mathrm{HeLa} / \mathrm{Bcl}-2$ cells downregulated their $\mathrm{COX}$

\footnotetext{
Figure $3 \mathrm{Bcl}-2$ expression exerts an effect on COX activity, oxygen consumption and downstream $\mathrm{O}_{2}^{-}$production. (a) Transient transfection led to transient overexpression of $\mathrm{Bcl}-2$ in transfected HeLa/Neo cells. The expression of Bcl-2 in HeLa/Neo cells was monitored over $72 \mathrm{~h}$ post-transfection by Western blot analysis. (b, $\mathbf{c}$ ) Increase in $\mathrm{Bcl}-2$ expression correlated with a transient increase in $\mathrm{COX}$ activity and intracellular $\mathrm{O}_{2}^{-}$. COX activity assay and $\mathrm{O}_{2}{ }^{-}$determination by lucigenin was performed on transiently transfected HeLa/Neo cells to observe the impact of Bcl-2 overexpression. (d) Bcl-2 was effectively and transiently silenced by specific siRNA. Bcl-2 expression in siRNA-transfected HeLa/Bcl-2 cells was assessed after $48 \mathrm{~h}$ post-transfection by Western blot analysis. (e, f) Transient reduction in Bcl-2 expression led to a corresponding decline in $\mathrm{COX}$ activity and intracellular $\mathrm{O}_{2}^{-}$. COX activity assay and $\mathrm{O}_{2}{ }^{-}$determination by lucigenin was performed on siRNA-transfected HeLa/Bcl-2 cells to observe the impact of Bcl-2 silencing. (g) Oxygen consumption was reduced in CEM/Bcl-2 cells treated with HA14-1. CEM/Bcl-2 cells were initially treated with HA14-1 for $2 \mathrm{~h}$ before isolated mitochondria were subjected to oxygen consumption measurements. Isolated mitochondria respired on succinate, a Complex II substrate and State 3 respiration was used as basis for comparison. As a control, isolated mitochondria of CEM/Neo cells treated likewise with HA14-1 resulted in increased oxygen consumption, similar to observations reported elsewhere. ${ }^{17}$ (h) Dose-dependent inhibition profile of COX by sodium azide. Dotted line indicates concentration of sodium azide required to reduce COX activity in CEM/BCl-2 cells to a similar level as untreated CEM/Neo cells. Treatment with $100 \mu \mathrm{M}$ sodium azide for $1 \mathrm{~h}$ reduced oxygen consumption in both CEM/Neo and $\mathrm{CEM} / \mathrm{Bcl}-2$ cells when compared to their respective untreated controls. Treated $\mathrm{CEM} / \mathrm{Bcl}-2$ cells consumed oxygen at a level comparable to untreated control $\mathrm{CEM} / \mathrm{Neo}$ cells. (i) Intramitochondrial $\mathrm{O}_{2}^{-}$production between $\mathrm{CEM} / \mathrm{Neo}$ and $\mathrm{CEM} / \mathrm{Bcl}-2$ cells was compared upon varying concentrations of sodium azide treatments. The error bars in $\mathbf{b}$, $\mathbf{c}$, $\mathbf{e}, \mathbf{f}$ and $\mathbf{g}-\mathbf{i}$ represent the mean \pm s.d $(n=3)$
} 
a

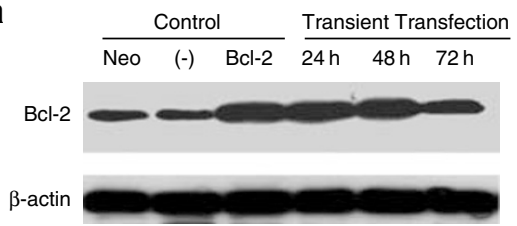

C

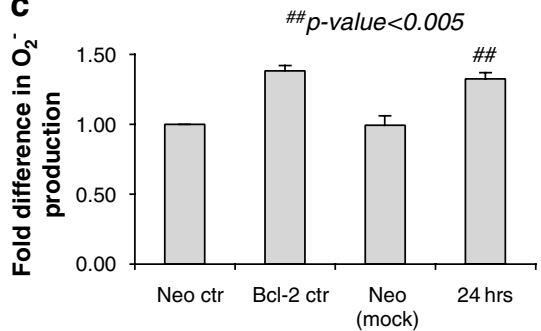

e
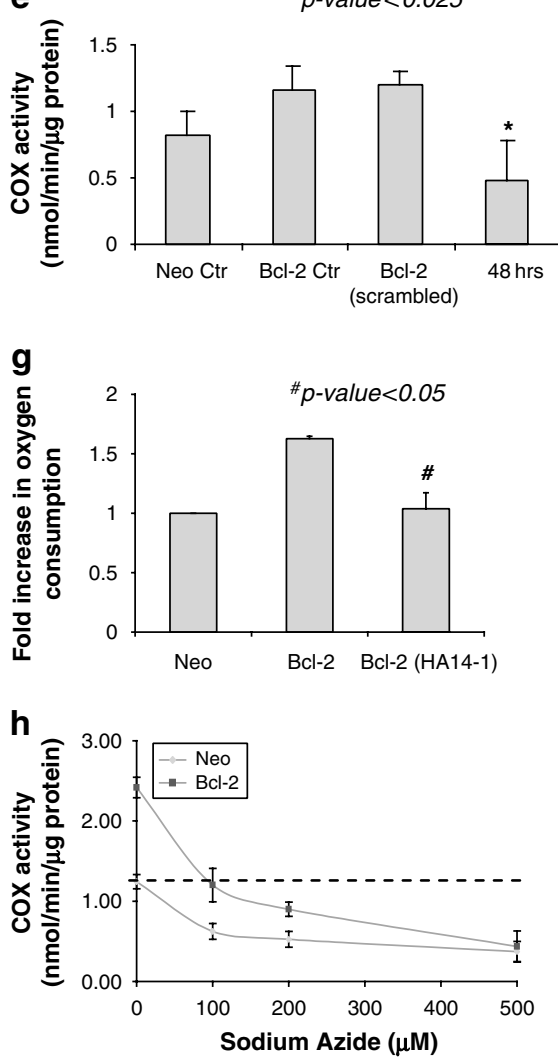

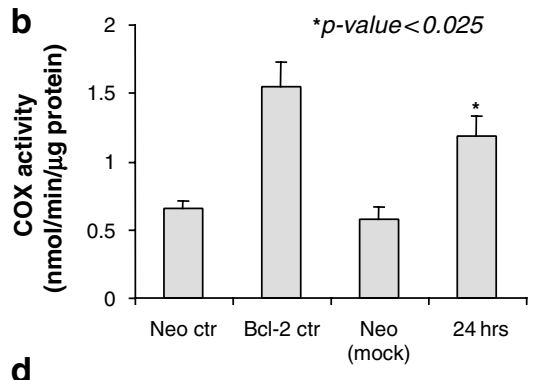

d

KD KD (2) $\mathrm{NeO} \quad \mathrm{Bcl}-2$

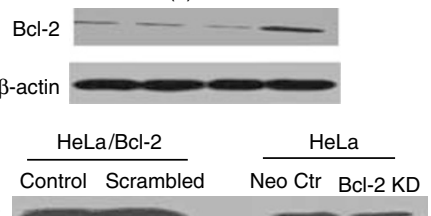

Bcl-2
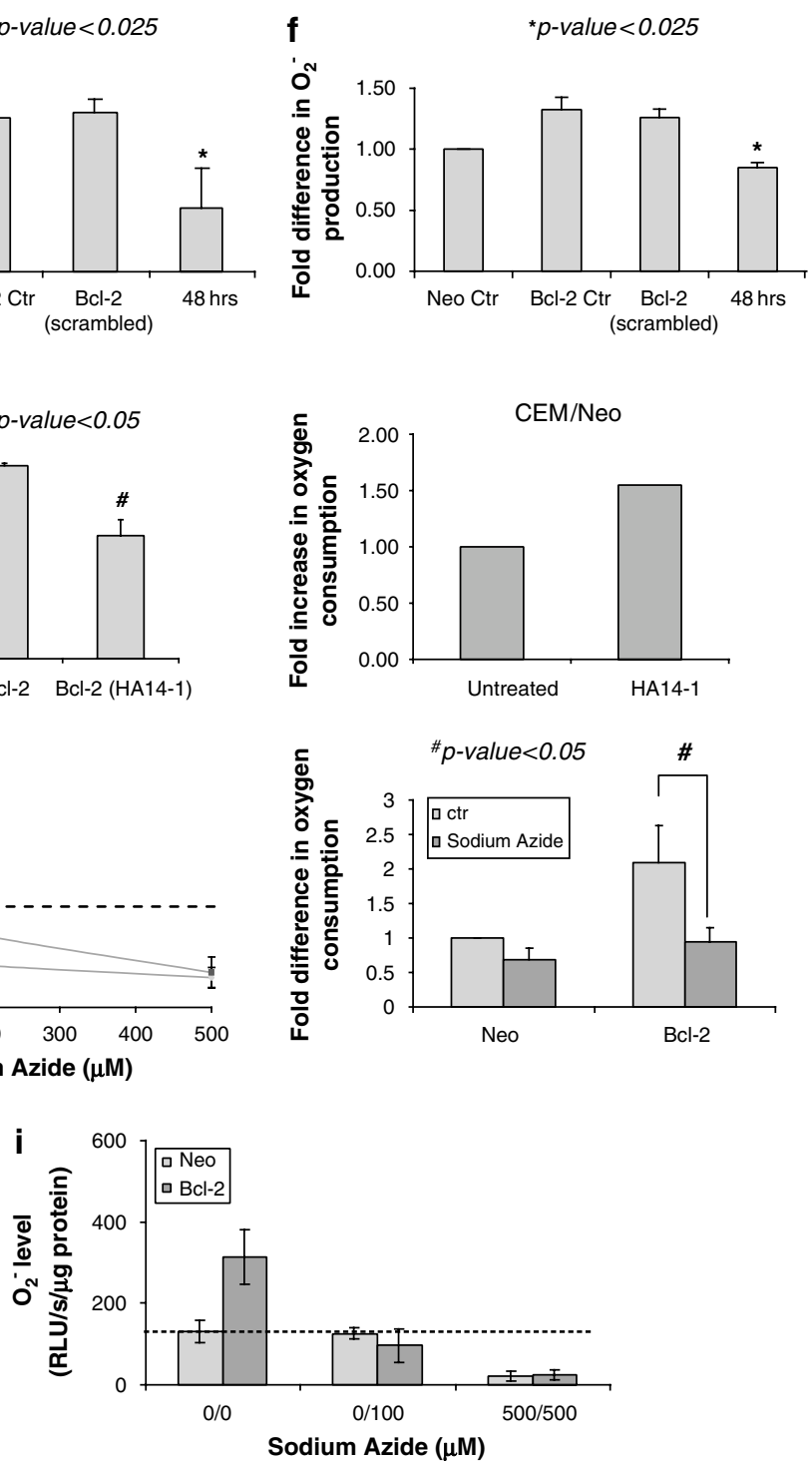

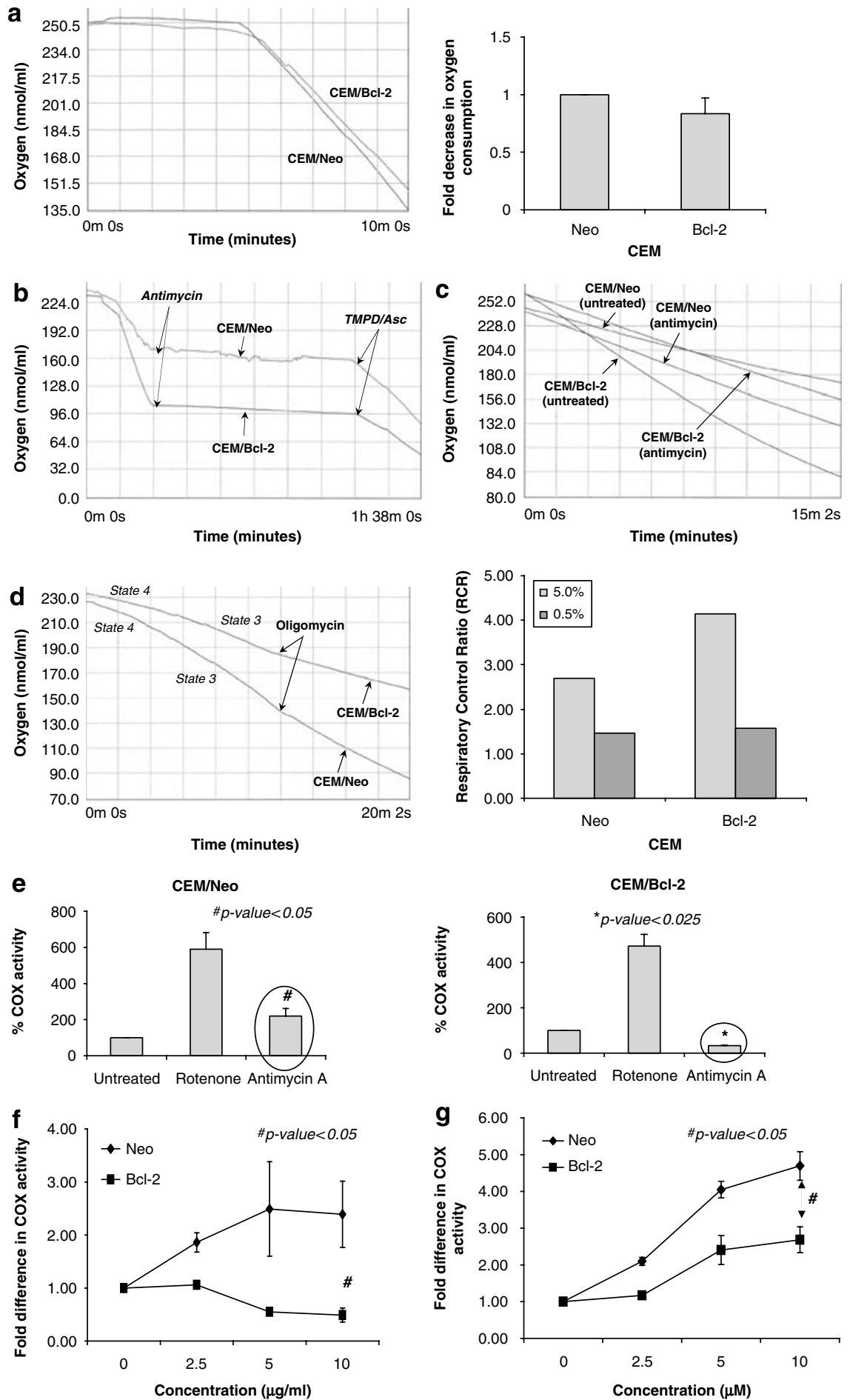

Figure $4 \mathrm{CEM} / \mathrm{BCl}-2$ cells downregulate oxygen consumption and COX activity during oxidative stress. (a) Oxygen consumption profile of isolated mitochondria from antimycin A-treated cells respiring on TMPD/ascorbate. Comparison of TMPD/ascorbate-driven oxygen consumption between isolated mitochondria of both CEM cell lines treated with antimycin A. (b) Oxygen consumption profile of isolated mitochondria before and after antimycin A treatment. Antimycin A directly induced a comparative disparity in oxygen consumption of isolated mitochondria. Antimycin A was added directly to the isolated mitochondria respiring on succinate in the chambers and incubated for $1 \mathrm{~h}$, before respiration was reinitiated by TMPD/ascorbate. (c) Oxygen consumption profile of isolated mitochondria comparing TMPD/ascorbate-driven respiration between untreated and antimycin A-treated cells in both cell lines. (d) Oxygen consumption profile of isolated mitochondria derived from cell lines that underwent $24 \mathrm{~h}$ of serum deprivation-induced oxidative stress. Normal serum $-5 \%$; serum deprivation $-0.5 \%$. Oxidative stress from serum deprivation induced uncoupled respiration in both $\mathrm{CEM}$ cell lines, evident from the comparison of RCR values. (e) $\mathrm{COX}$ activity of $\mathrm{CEM} / \mathrm{NeO}$ and $\mathrm{CEM} / \mathrm{BCl}-2$ cells treated with the various complex inhibitors was measured and percentage change was assessed relative to their respective untreated controls. (f, $\mathbf{g}) \mathrm{COX}$ activity in $\mathrm{HeLa} / \mathrm{NeO}$ and $\mathrm{HeLa} / \mathrm{Bcl}-2$ cells was assessed based on the difference in activity between the respective untreated control and treated samples. Dose-dependent response profiles for antimycin A and rotenone were obtained. The error bars in a and $\mathbf{e}-\mathbf{g}$ represent the mean $\pm \mathrm{s} . \mathrm{d}(n=3)$ 
activity (Figure 4f). Hence, it was beguiling to notice that the COX activity was on an upward trend in both rotenone-treated $\mathrm{HeLa} / \mathrm{Neo}$ and $\mathrm{HeLa} / \mathrm{Bcl}-2$ cells, albeit $\mathrm{HeLa} / \mathrm{Neo}$ cells increased nearly twice as much as HeLa/Bcl-2 cells (Figure $4 \mathrm{~g}$ ). We postulate that this disparity in modulation upon rotenone- and antimycin A-induced oxidative burst could be due to the difference in topology where ROS is accumulated, in relation to the localization of Bcl-2.

It is important to note that the variations in COX activity and oxygen consumption upon antimycin $A$ or rotenone treatments is neither due to a compromise in viability of $\mathrm{CEM} / \mathrm{Bcl}-2$ cells nor a proliferative effect on $\mathrm{CEM} / \mathrm{Neo}$ cells (Supplementary Figure S3A, B).

Maintenance of intramitochondrial $\mathrm{O}_{2}^{-}$level in $\mathrm{CEM} / \mathrm{Bcl}-2$ cells upon antimycin A treatment. Isolated mitochondria from $\mathrm{CEM} / \mathrm{Neo}$ and $\mathrm{CEM} / \mathrm{Bcl}-2$ cells respiring on succinate at $37^{\circ} \mathrm{C}$, were subsequently treated with $5 \mu \mathrm{g} / \mathrm{ml}$ antimycin $A$ (15-90 min) and $\mathrm{O}_{2}^{-}$levels were ascertained by lucigeninbased assay. $\mathrm{O}_{2}^{-}$level increased with time in treated $\mathrm{CEM} /$ Neo mitochondria (Figure 5a). In contrast, CEM/Bcl-2 mitochondria displayed minimal variation in their $\mathrm{O}_{2}^{-}$level. Untreated CEM/Bcl-2 mitochondria had higher levels of $\mathrm{O}_{2}^{-}$ than untreated CEM/Neo mitochondria (Figure 5a). This fold difference over untreated CEM/Neo was largely maintained upon antimycin $\mathrm{A}$ treatment of $\mathrm{CEM} / \mathrm{Bcl}-2$. It is evident that the $\mathrm{O}_{2}^{-}$level in $\mathrm{CEM} / \mathrm{Bcl}-2$ mitochondria was maintained, if not somewhat decreased, during antimycin A treatment. The $\mathrm{O}_{2}^{-}$level in CEM/Neo mitochondria greatly exceeded that of CEM/Bcl-2 after $90 \mathrm{~min}$ of treatment (Figure 5a). Using MitoSOX Red, CEM/Neo and CEM/Bcl-2 cells were treated with antimycin $\mathrm{A}$ as before. The intramitochondrial $\mathrm{O}_{2}^{-}$level in CEM/Neo cells increased over the course of $90 \mathrm{~min}$ (Figure 5b). Conversely, there was no appreciable increase in intramitochondrial $\mathrm{O}_{2}^{-}$production in $\mathrm{CEM} / \mathrm{Bcl}-2$ cells (Figure 5b). As a form of control, untreated CEM/Bcl-2 cells consistently demonstrated higher level of intramitochondrial $\mathrm{O}_{2}^{-}$than untreated $\mathrm{CEM} / \mathrm{Neo}$ cells (Figure $5 \mathrm{~b}$ ). These data argue in favor of a direct effect of $\mathrm{Bcl}-2$ on $\mathrm{COX}$ and mitochondrial respiration within the mitochondria. We speculate that the ability of $\mathrm{Bcl}-2$ overexpressing tumor cells to fine-tune mitochondrial respiration by downregulating its COX activity in times of oxidative stress must have a role in controlling ROS levels within the mitochondria.

Changes in cOX activity are not due to cOX and cytochrome $\boldsymbol{c}$ expression. Downregulation of COX activity in antimycin A-treated $\mathrm{CEM} / \mathrm{Bcl}-2$ cells is a function of oxidative stress. There was no distinct difference in COX subunit I (COXsI) expression between CEM/Neo and CEM/ $\mathrm{Bcl}-2$ cells (Figure $6 \mathrm{a}$ ). Treatment with varying doses of antimycin $A$ and rotenone for $1 \mathrm{~h}$ also failed to induce any change in the expression of COXsl, implying an effect on the intrinsic activity of $\mathrm{COX}$ by $\mathrm{Bcl}-2$ (Figure 6a). Similarly, total

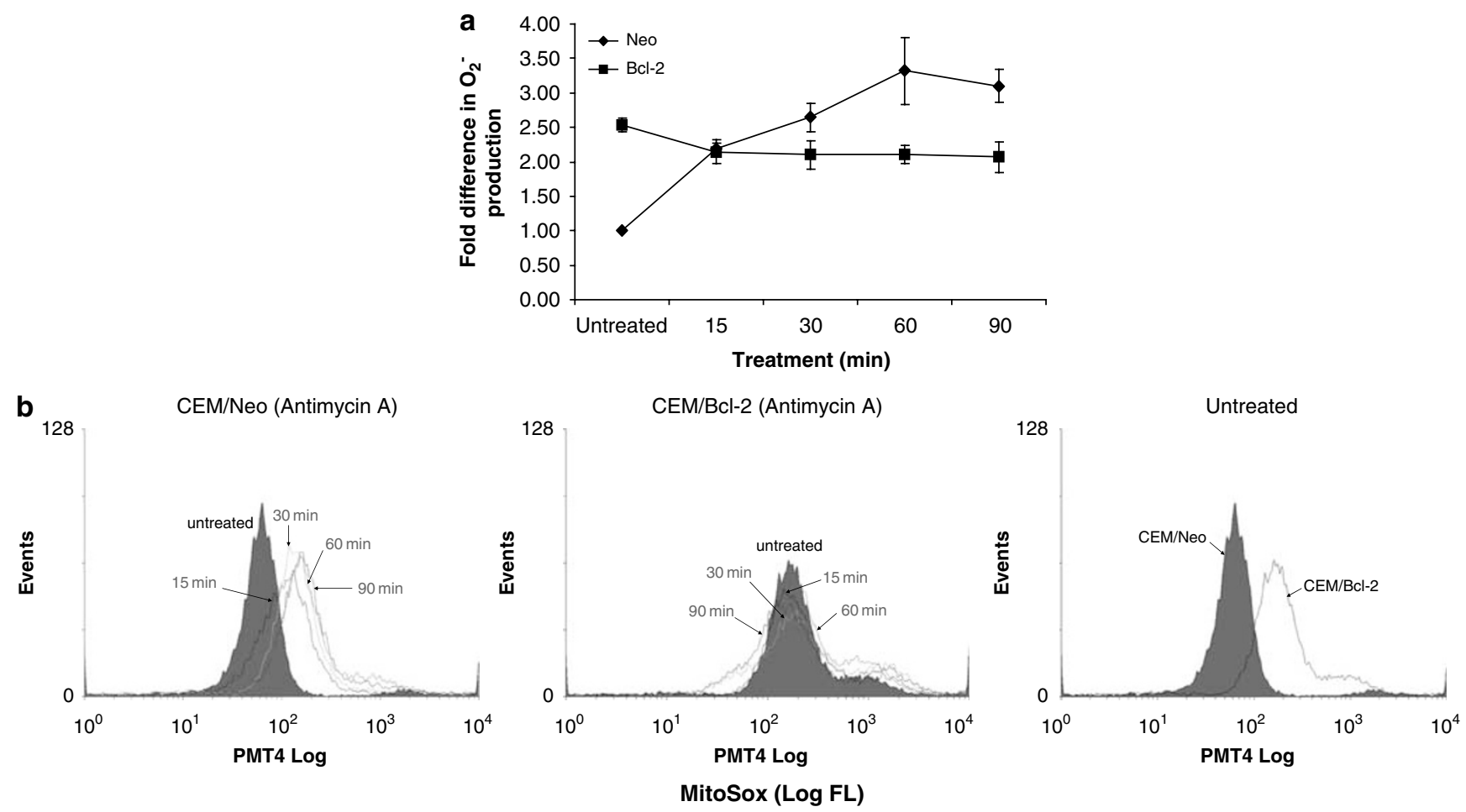

Figure 5 Mitochondrial $\mathrm{O}_{2}^{-}$production is maintained in $\mathrm{CEM} / \mathrm{Bcl}-2$ cells after antimycin A treatment. (a) Mitochondrial $\mathrm{O}_{2}^{-}$is maintained in isolated, antimycin A-treated CEM/Bcl-2 mitochondria and not CEM/Neo mitochondria. Isolated mitochondria of CEM cells respiring on succinate and treated with antimycin $\mathrm{A}$ were assessed for $\mathrm{O}_{2}{ }^{-}$ production over a 90 min time course by lucigenin assay. (b) Mitochondrial $\mathrm{O}_{2}{ }^{-}$is maintained in antimycin A-treated CEM/Bcl-2 cells and not CEM/Neo cells. CEM cells treated with antimycin A were assessed for intramitochondrial $\mathrm{O}_{2}{ }^{-}$production over the course of $90 \mathrm{~min}$ by MitoSOX Red and flow cytometry. The error bars in a represent the mean \pm s.d $(n=3)$. Experiments in $\mathbf{b}$ were repeated at least three times 
a

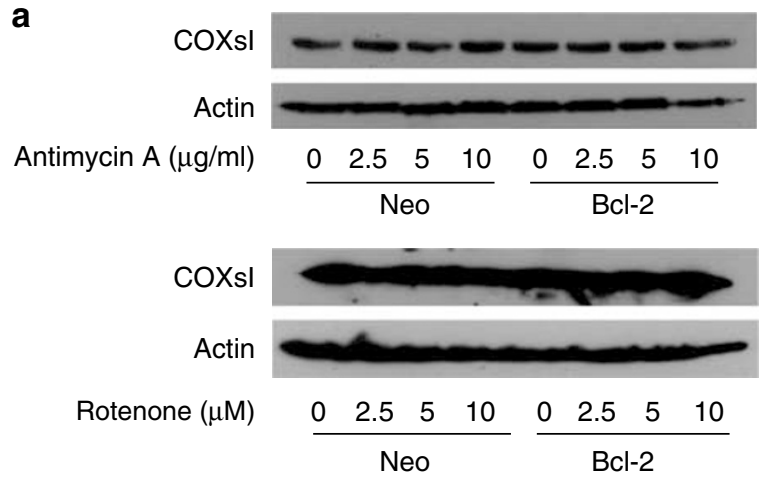

b

Cytochrome $c$

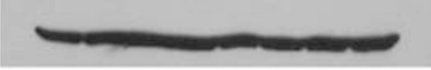

Actin

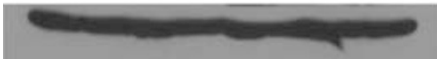

Antimycin A ( $\mu \mathrm{g} / \mathrm{ml})$

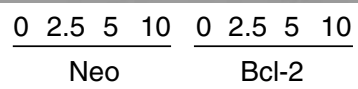

Cytochrome $c$

Actin

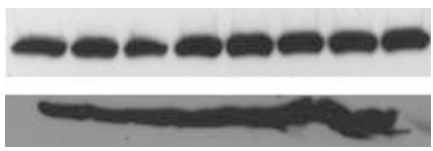

Rotenone $(\mu \mathrm{M})$
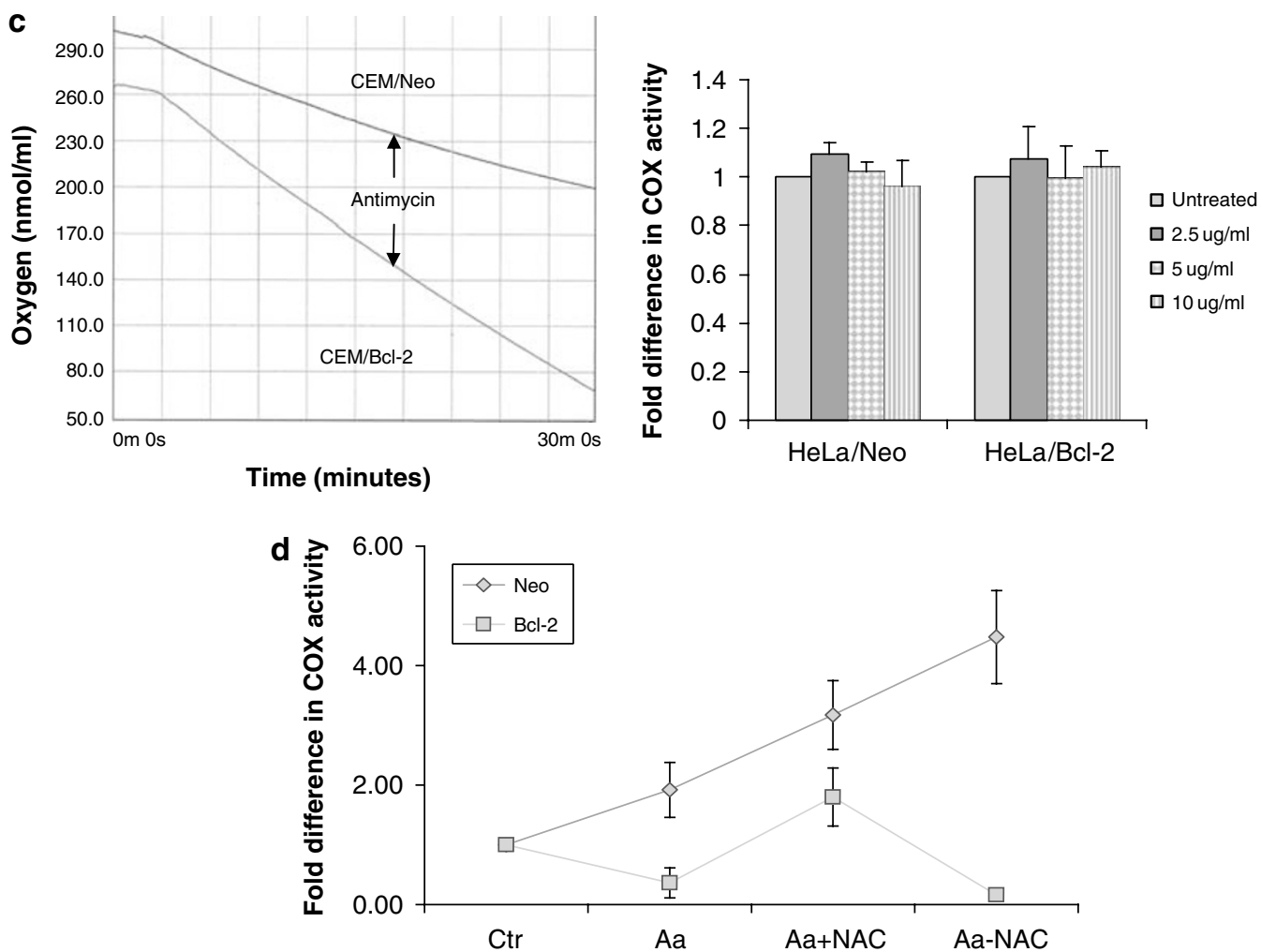

Figure 6 Differences in COX activity are not due to variation in expression of COXsl and cytochrome $c$. Oxidative burst is the primary causality for downregulation of COX activity in antimycin A-treated CEM/Bcl-2 cells. (a) Expression of COXsl remained unchanged despite treatment with antimycin $\mathrm{A}$ and rotenone. CEM/Neo and CEM/Bcl-2 cells treated with varying doses of antimycin $A$ and rotenone were analyzed for COXsl expression by Western blotting. (b) Total cytochrome $c$ remained unchanged with similar treatments. Both CEM cell lines were analyzed for total cytochrome $c$ levels after similar treatments. (c) Antimycin A itself did not alter TMPD/ascorbate-initiated oxygen consumption in the isolated mitochondria of both CEM cell lines. TMPD/ascorbate-driven respiration was recorded before and after direct antimycin $\mathrm{A}$ treatment on the isolated mitochondria of CEM cells. Antimycin A treated directly on isolated COX, albeit without succinate, has no effect on its activity in HeLa/Neo and HeLa/Bcl-2 cells. Isolated COX from HeLa cells was treated directly with antimycin A for $1 \mathrm{~h}$ and assayed for $\mathrm{COX}$ activity with reduced cytochrome $c$. (d) The downregulation of $\mathrm{COX}$ activity in antimycin Atreated $\mathrm{CEM} / \mathrm{Bcl}-2$ cells was ROS-dependent and irreversible. NAC was used to quench global ROS production. (Aa) stands for antimycin $\mathrm{A}$. (Aa + NAC) indicates cotreatment. (Aa-NAC) indicates $1 \mathrm{~h}$ of antimycin A treatment followed by $1 \mathrm{~h}$ of NAC treatment. The error bars in $\mathrm{C}$ and $\mathrm{D}$ represent the mean $\pm \mathrm{s} . \mathrm{d}(n=3)$. ( $\downarrow)$ in $\mathrm{C}$ denotes antimycin $\mathrm{A}$ administration

expression level of cytochrome $c$ was also consistent in both cell lines with or without treatment (Figure 6b). These data suggest that the changes in COX activity and mitochondrial respiration were most likely due to a gain or loss of function in COX activity, rather than an effect on its expression.

Besides, antimycin A-induced downregulation of COX activity in $\mathrm{CEM} / \mathrm{Bcl}-2$ cells is a function of intramitochondrial $\mathrm{O}_{2}^{-}$and not an effect of the inhibitor itself. TMPD/ascorbate- induced oxygen consumption remained higher in $\mathrm{CEM} / \mathrm{Bcl}-2$ isolated mitochondria than $\mathrm{CEM} / \mathrm{Neo}$ both before and after direct antimycin A treatment (Figure $6 \mathrm{c}$ ). This is presumably because no oxidative burst was produced by antimycin $A$ as TMPD/ascorbate-dependent respiration was downstream of Complex III inhibition and any upstream substrate (e.g. succinate) was absent. Likewise, preincubation of isolated COX with increasing doses of antimycin $A$ for $1 \mathrm{~h}$ without 
succinate did not elicit any change in COX activity in both $\mathrm{HeLa} / \mathrm{NeO}$ and $\mathrm{HeLa} / \mathrm{Bcl}-2$ cells, further confirming the role of stress-induced $\mathrm{O}_{2}^{-}$in $\mathrm{Bcl}-2$-regulated COX activity (Figure $6 \mathrm{c}$ ). Co-treatment of CEM/Bcl-2 cells with $5 \mu \mathrm{g} / \mathrm{ml}$ antimycin $A$ and $20 \mathrm{mM} \mathrm{N}$-acetyl cysteine (NAC) for $1 \mathrm{~h}$ did not result in downregulation of COX activity, unlike initial treatment with antimycin $A$ for $1 \mathrm{~h}$ followed by NAC for another $1 \mathrm{~h}$ (Figure $6 \mathrm{~d}$ ). Taken together, these data indicate that in the presence of electron transport blockade by complex inhibition results in an upregulation of downstream COX activity regardless of $\mathrm{O}_{2}^{-}$status, unless in the context of $\mathrm{Bcl}-2$ overexpression. Furthermore, antimycin A-induced downregulation of $\mathrm{COX}$ activity in $\mathrm{CEM} / \mathrm{Bcl}-2$ cells was irreversible even upon scavenging intracellular ROS.

\section{Discussion}

Our study revealed that tumor cells stably overexpressing Bcl2 have marked increase in oxygen consumption and COX activity, which primarily accounts for the higher mitochondrial $\mathrm{O}_{2}^{-}$produced and in turn, contributing at least in part, to the slight pro-oxidant state in $\mathrm{CEM} / \mathrm{Bcl}-2$ cells. ${ }^{9}$

More importantly, the impact of $\mathrm{Bcl}-2$ on mitochondrial respiration is not unidirectional. Periods of oxidative distress lead to adjustment in oxygen consumption and COX activity, facilitated by the overexpression of $\mathrm{Bcl}-2$. We propose the modulation in mitochondrial respiration as a novel mechanism to regulate ROS level at an optimal threshold, favoring survival even in the presence of ROS inducers such as antimycin A or serum deprivation. This protective mechanism, together with other classical antioxidant defence systems such as superoxide dismutase (SOD), prevents ROS production from reaching detrimental levels. In our system, we reason that the involvement of SOD in mediating the maintenance of mitochondrial $\mathrm{O}_{2}^{-}$in $\mathrm{CEM} / \mathrm{Bcl}-2$ cells during antimycin $A$ treatment is at best, minimal. The SOD isoform responsible for quenching mitochondrial $\mathrm{O}_{2}^{-}$is predominantly MnSOD (SOD II), which has been shown to localize to the mitochondrial matrix. On the other hand, the production of $\mathrm{O}_{2}^{-}$ by antimycin A inhibition of Complex III was reported to be largely confined to the cytoplasmic side of the inner mitochondrial membrane. ${ }^{21}$ In other words, most of the ROS produced is extruded and strewn within the intermembrane space. Moreover, previous work has also shown that $\mathrm{O}_{2}^{-}$in its anionic form is too strongly charged to readily cross the inner mitochondrial membrane. ${ }^{22}$ On the basis of this knowledge, it seems unlikely for MnSOD to be able to access the $\mathrm{O}_{2}^{-}$produced by Complex III upon antimycin A treatment, thereby limiting its influence on $\mathrm{O}_{2}^{-}$levels in the treated CEM/ $\mathrm{Bcl}-2$ cells. Indeed, if MnSOD was engaged in blunting mitochondrial $\mathrm{O}_{2}^{-}$increase in antimycin A-treated $\mathrm{CEM} / \mathrm{Bcl}-2$ cells due to increased activity in the context of $\mathrm{Bcl}-2$ overexpression, then the observation of untreated $\mathrm{CEM} / \mathrm{Bcl}-$ 2 cells consistently displaying higher mitochondrial $\mathrm{O}_{2}^{-}$ production as compared to untreated $\mathrm{CEM} / \mathrm{Neo}$ cells clearly refutes the earlier argument.

It has been reported that HA14-1 increased mitochondrial respiration due to uncoupling and led to ROS production in CEM cells. ${ }^{17}$ Indeed, we reported increased oxygen consumption in $\mathrm{CEM} / \mathrm{Neo}$ cells treated in similar fashion.
However, we reason two possible alternative scenarios for our observation in CEM/Bcl-2 cells. Firstly, it may be likely that the reduction in oxygen consumption caused by the inhibition of $\mathrm{Bcl}-2$ could more than compensate for the intrinsic capability of HA14-1 to raise uncoupled mitochondrial respiration in $\mathrm{CEM} / \mathrm{Bcl}-2$ cells, with the outcome being reduced $\mathrm{ROS}$ generation and overall decreased oxygen consumption. On the other hand, the result of increased uncoupled mitochondrial respiration and ROS production in CEM cells as reported previously was observed in the absence of $\mathrm{Bcl}-2$ overexpression. Thus, it may be conceivable that the overexpression of $\mathrm{Bcl}-2$ abrogates the effect of HA141 by sensing ROS status and downregulating mitochondrial respiration accordingly to maintain ROS at a manageable level. Indeed, if $\mathrm{Bcl}-2$ inhibitor $\mathrm{HA} 14-1$ uncouples mitochondrial respiration in CEM cells, it might be plausible to imply that $\mathrm{Bcl}-2$ would make an unlikely uncoupling candidate. ${ }^{17}$

Nevertheless, from the respiratory control exerted by Bcl-2 on the rate-limiting enzyme COX, its appears that the CEM/ $\mathrm{Bcl}-2$ cells are able to discern between the threat posed by potentially overwhelming ROS and the 'energy cutoff' triggered by antimycin $A$, adjusting mitochondrial respiration accordingly to keep ROS level under control. The regulation of COX activity and oxygen consumption brought respirationdependent $\mathrm{O}_{2}^{-}$production under control and this may be effective in protecting cells against mitochondrial dysfunction and ROS-induced apoptosis.

It is promising to unravel the workings of antiapoptotic proteins, in the like of $\mathrm{Bcl}-2$ on metabolism and respiration. The establishing of this relationship between $\mathrm{Bcl}-2$ and $\mathrm{COX}$ opens up a new paradigm in apoptotic evasion by cancer cells and their altered sensitivities to treatment with ROS-inducing chemotherapeutics. By virtue of an increased Bcl-2 expression profile, cancer cells might be able to remain resistant to ROS-inducing death triggers by elegantly manipulating their mitochondrial respiration profiles, keeping potentially deleterious level of ROS at bay, whereas maintaining a slight prooxidant milieu under basal conditions, conducive for survival. Our work suggests that the engagement of the mitochondrial respiration machinery contributes to this phenomenon.

\section{Materials and Methods}

Cell culture. CEM human leukemia cells stably transfected with the control vector (CEM/Neo) or Bcl-2 (CEM/Bcl-2) were maintained in RPMI 1640 supplemented with $2 \mathrm{mM}$ L-glutamine, $1 \%$ streptomycin-penicillin (v/v) and $5 \%$ fetal bovine serum (FBS; v/v). G418 disulphate salt solution was added as a selective antibiotic for the maintenance of stable transfectants. Jurkat cells were from human T-cell leukemia stably transfected with the above-mentioned vectors and cultured under conditions as described previously. HeLa cells were derived from cervical carcinoma, which have been transformed by human papillomavirus 18 (HPV18). These cells were stably transfected with the same vectors as described for CEM and Jurkat cells and maintained in Dulbecco's modified Eagle's medium containing $10 \% \mathrm{FBS}(\mathrm{v} / \mathrm{v})$. All the cell lines were cultured in a humidified incubator at $37^{\circ} \mathrm{C}$ and $5 \% \mathrm{CO}_{2}$.

Isolation of intact mitochondria. Cells were harvested and washed once with ice-cold $1 \times$ PBS and spun down by centrifugation at 1200 r.p.m. for 5 min at $4^{\circ} \mathrm{C}$. The pellet was resuspended in 10 volumes of extraction buffer $(200 \mathrm{mM}$ mannitol, $68 \mathrm{mM}$ sucrose, $50 \mathrm{mM}$ Pipes-KOH (pH 7.4), $50 \mathrm{mM} \mathrm{KCl,} 5 \mathrm{mM}$ EGTA, $2 \mathrm{mM} \mathrm{MgCl} 2$ and1 $\mathrm{mM}$ dithiothreitol), containing various protease inhibitors (1 $\mathrm{mM}$ phenylmethanesulfonylfluoride, $10 \mu \mathrm{g} / \mathrm{ml}$ aprotinin, $20 \mu \mathrm{g} / \mathrm{ml}$ pepstatin A and $10 \mu \mathrm{g} / \mathrm{ml}$ leupeptin) and incubated on ice for $20 \mathrm{~min}$. After incubation, the cells 
were homogenized with a dounce homogenizer and passaged for 30 strokes before being centrifuged at $300 \times g$ for $10 \mathrm{~min}$ at $4^{\circ} \mathrm{C}$. Following which, the supernatant was centrifuged again at $12000 \times g$ for $30 \mathrm{~min}$ at $4^{\circ} \mathrm{C}$. The pellet contains the intact mitochondria fraction.

Oxygen consumption. Oxygen consumption was measured using Oxytherm Electrode (Hansatech Instruments, Norfolk, UK) at $25^{\circ} \mathrm{C}$. The chambers were cleaned with distilled water. Isolated mitochondria were added to each chamber containing $1.25 \mathrm{ml}$ of mitochondrial buffer III $(200 \mathrm{mM}$ mannitol, $75 \mathrm{mM}$ sucrose, $10 \mathrm{mM}$ Tris-HCL (pH 7.4), $0.1 \mathrm{mM}$ EDTA, $10 \mathrm{mM} \mathrm{K}_{2} \mathrm{HPO}_{4}$ and $10 \mathrm{mM} \mathrm{KCl}$ ). State 4 mitochondrial respiration was stimulated by adding $10 \mathrm{mM}$ succinate, $80 \mu \mathrm{M}$ ATP and $5 \mu \mathrm{M}$ rotenone. State 3 respiration was initiated with $0.2 \mathrm{mM}$ ADP. Data acquisition and analysis was carried out using Oxygraph Plus developed for high-resolution respirometry (Hansatech Instruments, Norfolk, UK).

Cytochrome $c$ oxidase isolation and activity. Cells were dissolved in $2 \mathrm{ml}$ of COX buffer ( $250 \mathrm{mM}$ sucrose, $2 \mathrm{mM}$ HEPES and $0.1 \mathrm{mM} \mathrm{EGTA}$ at $\mathrm{pH} 7.4$ ) before being centrifuged at $330 \times g$ for $10 \mathrm{~min}$ at $4^{\circ} \mathrm{C}$. The cells were then resuspended with $1 \mathrm{ml}$ of COX buffer and incubated for $10 \mathrm{~min}$ at $4{ }^{\circ} \mathrm{C}$ before being subjected to homogenization for 10 passages and the cell lysate was spun at $600 \times g$ for $10 \mathrm{~min}$ at $4^{\circ} \mathrm{C}$. The supernatant was then centrifuged at $14400 \times g$ for $10 \mathrm{~min}$ at $4^{\circ} \mathrm{C}$. The resultant pellet is the purified mitochondria fraction, containing COX. The pellet was dissolved in $100 \mu$ l of prewarmed potassium phosphate buffer at $\mathrm{pH} 7.2$ and incubated at room temperature (RT) for $3 \mathrm{~min}$. COX activity was measured by monitoring the oxidation of reduced cytochrome $c$ by spectrophotometric analysis at $550 \mathrm{~nm}$ for $2 \mathrm{~min}$ at $37^{\circ} \mathrm{C}$ using BioSpec- 1601 spectrophotometer (Shimadzu, Japan). COX activity was determined by measuring the decrease in absorbance of ferrocytochrome $c$ caused by its oxidation to ferricytochrome $c$ by COX.

Transient transfection. Transient transfection of $\mathrm{HeLa} / \mathrm{NeO}$ cells was performed using the SuperFect ${ }^{\circledR}$ Transfection Reagents from QIAGEN GmbH (Germany). Briefly, $3 \mu \mathrm{g}$ of the pIRES (empty vector) or pcDNA3-Bcl-2 was added to $20 \mu$ of the SuperFect ${ }^{\circledR}$ Transfection Reagent and transfection was carried out as recommended by the vendor. Bcl-2 expression was detected from the cell lysates at the various post-transfection time points by Western blotting using a primary mouse monoclonal anti-Bcl-2 antibody at 1:1000 dilution (Santa Cruz, CA, USA) and a secondary horseradish peroxidase (HRP)-conjugated goat anti-mouse IgG at 1:5000 dilution (Pierce, IL, USA).

RNA interference. HeLa/Bcl-2 cells were transfected 96,72 and $48 \mathrm{~h}$ before COX activity and $\mathrm{O}_{2}^{-}$measurement experiments with $0.2 \mu \mathrm{M} \mathrm{Bcl-2-specific} \mathrm{siRNA}$ (QIAGEN, GmbH, Germany) or scrambled siRNA duplexes by using Oligofectamine ${ }^{\mathrm{TM}}$ reagent according to the manufacturer's instructions (Invitrogen, CA, USA). Expression level of Bcl-2 was confirmed by Western blotting using antibodies as described previously for the detection of Bcl-2.

$\mathbf{O}_{2}^{-}$measurement by lucigenin. A lucigenin-based chemiluminescence assay was used for measuring intracellular $\mathrm{O}_{2}^{-}$as described previously. ${ }^{23}$ Chemiluminescence was monitored using a Berthold Sirius Luminometer (Berthold detection systems $\mathrm{GmbH}$, Bleichstrabe/Pforzheim/Germany). The assay was also used to detect $\mathrm{O}_{2}^{-}$level in isolated mitochondria in some instances. Data are described as relative light units/s/ $\mu \mathrm{g}$ of protein ( $\mathrm{RLU} / \mathrm{s} / \mu \mathrm{g}$ protein).

$\mathrm{O}_{2}^{-}$measurement by MitoSOX Red. $\mathrm{O}_{2}^{-}$production from the mitochondria was also specifically monitored by MitoSOX Red (Invitrogen, CA, USA), which is a fluorescent probe targeted to the mitochondria and highly susceptible to oxidation by $\mathrm{O}_{2}^{-}$. Briefly, $1 \times 10^{6}$ cells were incubated with $10 \mu \mathrm{M}$ MitoSOX Red reagent for $15 \mathrm{~min}$ at $37^{\circ} \mathrm{C}$. Cells were washed twice with $1 \times$ PBS and immediately analyzed in Epic Profile flow cytometer with excitation set at $510 \mathrm{~nm}$. Data were analyzed for 10000 events using the WinMDI software.

Western blotting. Proteins were analyzed and resolved on a $12 \%(\mathrm{v} / \mathrm{v})$ acrylamide resolving gel, subjected to SDS-PAGE. The resolved proteins were then transferred onto a polyvinyldifluoride (PVDF) membrane by the semi-dry transfer method using the Hoefer ${ }^{\mathrm{TM}}$ TE 77 semi-dry transfer unit (Amersham Biosciences, NJ, USA). The membrane was then blocked with $5 \%(\mathrm{w} / \mathrm{v})$ fat-free milk in Trisbuffered saline containing $0.05 \%(\mathrm{v} / \mathrm{v})$ Tween 20 (TBST) for $1 \mathrm{~h}$. After three washes with TBST to remove excess milk, the membrane was probed for the protein of interest with the relevant primary antibody in $5 \%(\mathrm{w} / \mathrm{v})$ bovine serum albumin in TBST at $4{ }^{\circ} \mathrm{C}$ for $1-2 \mathrm{~h}$. The membrane was subsequently subjected to three washes with TBST to remove unbound primary antibody and probed again with the appropriate HRP-conjugated secondary antibody in TBST containing $1 \%(\mathrm{w} / \mathrm{v})$ fatfree milk for $1 \mathrm{~h}$ at RT. After three washes with TBST to remove any excess unbound secondary antibody, the desired probed proteins were next detected with Kodak Biomax MR X-ray film by enhanced chemiluminescence using the SuperSignal Chemiluminescent Substrate (Pierce, IL, USA). The primary and secondary antibodies for the probing by Western blot analysis were applied at 1:1000 and $1: 5000$ dilutions, respectively.

Cell viability assay. Cells were added with $3 \mathrm{mg} / \mathrm{ml}$ of $3-(4,5-$ dimethylthiazolyl-2)-2,5-diphenyl tetrazolium bromide in plain RPMI 1640 and incubated for $1-2 \mathrm{~h}$ at $37^{\circ} \mathrm{C}$. The cells were then centrifuged at $3000 \times$ r.p.m. for $5 \mathrm{~min}$ before being redissolved in DMSO, containing Sorensen's glycine buffer $(0.1 \mathrm{M}$ glycine and $0.1 \mathrm{M} \mathrm{NaCl}, \mathrm{pH} 10.5)$. Cell viability was determined spectrophotometrically, with absorbance wavelength of $570 \mathrm{~nm}$.

Acknowledgements. This work is supported by grants from the National Medical Research Council, the Biomedical Research Council, and the NUS Academic Research Fund to SP The authors wish to thank Jayshree L Hirpara and Rathiga Velaithan for rendering generous technical assistance and advisory support as well as Dr. Deng Yuru and Dr. Wang Chunming for the provision of Hansatech Oxytherm electrodes for oxygen consumption studies.

1. Bensaad K, Tsuruta A, Selak MA, Vidal MN, Nakano K, Bartrons R et al. TIGAR, a p53inducible regulator of glycolysis and apoptosis. Cell 2006; 126: 107-120.

2. Matoba S, Kang JG, Patino WD, Wragg A, Boehm M, Gavrilova $O$ et al. p53 regulates mitochondrial respiration. Science 2006; 312: 1650-1653.

3. Kruse JP, Gu W. p53 aerobics: the major tumor suppressor fuels your workout. Cell Metab 2006; 4: 1-3

4. Shibasaki F, Kondo E, Akagi T, McKeon F. Suppression of signalling through transcription factor NF-AT by interactions between calcineurin and Bcl-2. Nature 1997; 386: 728-731.

5. Hirai I, Wang HG. Survival-factor-induced phosphorylation of Bad results in its dissociation from Bcl-x(L) but not Bcl-2. Biochem J 2001; 359: 345-352.

6. Harris $\mathrm{MH}$, Thompson $\mathrm{CB}$. The role of the $\mathrm{Bcl}-2$ family in the regulation of outer mitochondrial membrane permeability. Cell Death Differ 2000; 7: 1182-1191.

7. Chen Q, Vazquez EJ, Moghaddas S, Hoppel CL, Lesnefsky EJ. Production of reactive oxygen species by mitochondria: central role of complex III. J Biol Chem 2003; 278 : 36027-36031.

8. Grivennikova VG, Vinogradov AD. Generation of superoxide by the mitochondrial Complex I. Biochim Biophys Acta 2006; 1757: 553-561.

9. Clement MV, Hirpara JL, Pervaiz S. Decrease in intracellular superoxide sensitizes Bcl-2overexpressing tumor cells to receptor and drug-induced apoptosis independent of the mitochondria. Cell Death Differ 2003; 10: 1273-1285.

10. Adams ML, Pierce RH, Vail ME, White CC, Tonge RP, Kavanagh TJ et al. Enhanced acetaminophen hepatotoxicity in transgenic mice overexpressing BCL-2. Mol Pharmacol 2001; 60: 907-915.

11. Hockenbery D, Nunez G, Milliman C, Schreiber RD, Korsmeyer SJ. Bcl-2 is an inner mitochondrial membrane protein that blocks programmed cell death. Nature 1990; 348 334-336.

12. Nguyen M, Millar DG, Yong VW, Korsmeyer SJ, Shore GC. Targeting of Bcl-2 to the mitochondrial outer membrane by a $\mathrm{COOH}$-terminal signal anchor sequence. J Biol Chem 1993; 268: 25265-25268

13. Nijtmans LG, Taanman JW, Muijsers AO, Speijer D, Van den Bogert C. Assembly of cytochrome-c oxidase in cultured human cells. Eur J Biochem 1998; 254: 389-394.

14. Lee M, Hyun DH, Halliwell B, Jenner P. Effect of overexpression of wild-type and mutant $\mathrm{Cu} / \mathrm{Zn}$-superoxide dismutases on oxidative stress and cell death induced by hydrogen peroxide, 4-hydroxynonenal or serum deprivation: potentiation of injury by ALS-related mutant superoxide dismutases and protection by Bcl-2. J Neurochem 2001; 78: 209-220.

15. Kowaltowski AJ, Fenton RG, Fiskum G. Bcl-2 family proteins regulate mitochondrial reactive oxygen production and protect against oxidative stress. Free Radic Biol Med 2004; 37: $1845-1853$

16. Steinman HM. The Bcl-2 oncoprotein functions as a pro-oxidant. J Biol Chem 1995; 270 3487-3490.

17. Hao JH, Yu M, Liu FT, Newland AC, Jia L. Bcl-2 inhibitors sensitize tumor necrosis factorrelated apoptosis-inducing ligand-induced apoptosis by uncoupling of mitochondrial respiration in human leukemic CEM cells. Cancer Res 2004; 64: 3607-3616.

18. Zhuge J, Cederbaum Al. Serum deprivation-induced HepG2 cell death is potentiated by CYP2E1. Free Radic Biol Med 2006; 40: 63-74. 
19. Pelicano $\mathrm{H}$, Feng L, Zhou Y, Carew JS, Hileman EO, Plunkett $W$ et al. Inhibition of mitochondrial respiration: a novel strategy to enhance drug-induced apoptosis in human leukemia cells by a reactive oxygen species-mediated mechanism. J Biol Chem 2003; 278 : 37832-37839.

20. Li N, Ragheb K, Lawler G, Sturgis J, Rajwa B, Melendez JA et al. Mitochondrial complex inhibitor rotenone induces apoptosis through enhancing mitochondrial reactive oxygen species production. J Biol Chem 2003; 278: 8516-8525.
21. St-Pierre J, Buckingham JA, Roebuck SJ, Brand MD. Topology of superoxide production from different sites in the mitochondrial electron transport chain. J Biol Chem 2002; 277: 44784-44790.

22. Muller FL, Liu Y, Van Remmen H. Complex III releases superoxide to both sides of the inner mitochondrial membrane. J Biol Chem 2004; 279: 49064-49073.

23. Clement MV, Stamenkovic I. Superoxide anion is a natural inhibitor of FAS-mediated cell death. EMBO J 1996; 15: 216-225.

Supplementary Information accompanies the paper on Cell Death and Differentiation website (http://www.nature.com/cdd) 